\title{
PENINGKATAN KEMAMPUAN MENULIS KREATIF PUISI DENGAN MENGGUNAKAN MODEL PEMBELAJARAN KREATIF, KONTEKSTUAL, DAN RELIGIUS
}

\author{
Sri Suryani \\ Guru MTs N 2 Pontianak \\ e-mail:srisuryani1975@gemail.com
}

\begin{abstract}
Increasedability to writecreative poemsusing creative model of learning, contextual, andreligious (TRC) in the seventh grade studentsof MTs Negeri $2 A$ Pontianakconductedto determine the applicationthat is implemented in the classroomlearning. This studyaimed to describethe planning, execution, and learning outcomes. The method usedis descriptive method, the form of qualitative research, and the type of research is classroom action research (CAR). The data were taken using tests andnon-test instruments. Data collectiontool used. Was the observation sheet and achievement test. Data were analysed qualitatively and quantitatively. Based on this research, the TRC model of learning can improve student learning out comes in creative writing poetry. The average results of student learningin the first cycle was 69.65 or at $41.38 \%$, the second cycle increased to 73.79 or at $72.41 \%$, while the third cycle increased to 78.20 or at $89.66 \%$. Similarly, the attitudes of studentsin the following study very well increase.
\end{abstract}

\section{Keywords: Creative Writing Poetry, Model of Learning and Religious Contextual Creative.}

\section{PENDAHULUAN}

Keterampilan menulis merupakan keterampilan berbahasa dan bersastra yang sangat penting bagi siswa, baik selama mereka mengikuti pendidikan maupun setelah menyelesaikan pendidikan. Menurut Hairston (dalam Darmadi, 1996:3) "Kegiatan menulis dapat membantu diri kita untuk menyerap dan memroses informasi. Bila kita akan menulis sebuah topik maka hal itu berarti kita harus belajar tentang topik itu dengan lebih baik. Apabila kegiatan seperti itu kita lakukan terus menerus maka berarti dapat mempertajam kemampuan kita dalam menyerap dan memproses informasi”.

Menulis puisi merupakan salah satu keterampilan bidang apresiasi sastra yang harus dikuasai oleh siswa menengah pertama. Di dalam kurikulum bahasa Indonesia kelas VII semester genap terdapat pembelajaran materi menulis kreatif puisi berkenaan dengan keindahan alam. Dalam pembelajaran ini, siswa diharapkan mampu menuliskan apa yang dirasakan atau apa yang dipikirkan, serta apa yang dilihat ke dalam bahasa yang indah. Hal ini berkaitan erat dengan latihan mempertajam perasaan, penalaran, dan daya khayal, serta kepekaan terhadap lingkungan hidup.

Berdasarkan hasil refleksi di kelas VII A MTs Negeri 2 Pontianak, bahwakemampuan siswa dalam menulis kreatif puisi masih rendah. Dalam hal ini, peneliti menemukan $80 \%$ siswa mengalami kesulitan. Rata-rata siswa mendapat nilai 68, sehingga tidak memenuhi syarat Kriteria Ketuntasan Minimal (KKM) yaitu 72 yang ditetapkan oleh MTs Negeri 2 Pontianak.Rendahnya pencapaian nilai tersebut karena siswa mengalami kesulitan untuk menemukan ide yang akan dikembangkan menjadi sebuah puisi. Penguasaan kosa kata yang dimiliki siswa sangat minim sehingga siswa kesulitan menentukan dan merangkai diksi menjadi sebuah puisi. Di samping itu, pelaksanaan pembelajaran menulis kreatif puisi masih konvensional dan menulis puisi dilakukan di dalam kelas, sehingga siswa cenderung menjiplak puisi yang sudah ada di buku 
pelajaran.Dengan demikian, guru harus berinovasi mencari dan menemukan model pembelajaran yang tepat, guna meningkatkan kemampuan menulis kreatif puisi pada siswa.

Model pembelajaran yang peneliti anggap tepat untuk meningkatkan kemampuan menulis kreatif puisi siswa adalah model pembelajaran Kreatif, Kontekstual, dan Religius (KKR).Pembelajaran kreatif, kontekstual, dan religius adalahsebuah konsep pembelajaran yang berusaha menciptakan suasana pembelajaran yang dinamis dan merangsang munculnya ide-ide kreatif, adanya interaksi pembelajaran yang mengomunikasikan dan mengembangkan kecakapan hidup, serta berusaha menanamkan nilai-nilai spiritual keagamaan/religius,dengan langkahlangkah sebagai berikut: 1) guru menjelaskan kepada siswa tentang tujuan pembelajaran dengan menjelaskan kompetensi dasar dan indikator-indikator yang akan dicapai dalam kegiatan belajar (introduce); 2) Guru mendorong siswa untuk menghubungkan materi yang dipelajari dengan pengetahuan, keterampilan, dan pengalaman yang sudah dimiliki siswa (connect);

3) Guru mampu membimbing dan mendorong siswa untuk mempraktikkan apa yang telah dipelajari (apply); 4) mengartikulasikan pengetahuan yang sudah dipelajari dengan cara lisan atau tulisan (reflect); 5) Guru mendorong siswa agar bisa merencanakan apa yang akan dilakukan untuk belajar lebih banyak, mendapatkan informasi lebih banyak, dan memiliki kecakapan lebih banyak pula dari materi yang sudah dipelajari (extend) ( Amin, 2007:332).

Inti dari model pembelajaran ini adalah pembelajaran icare. Icare dilaksanakan di dalam proses pembelajaran mulai dari pengenalan materi puisi sampai pada cara menulis puisi yang secara langsung dialami siswa pada alam terbuka, sehingga siswa mendapatkan ide yang dituangkan dalam bentuk puisi yang di dalamnyaterdapat diksi, gaya bahasa, dan citraan. Siswa yang selama ini kesulitan menentukan diksi, setelah melihat pemandangan di alam terbuka siswa dapat mendata katakata dari apa yang dilihatnya, dirasakan, didengar, dicium, dan dicecap yang dapat merangsang kreativitas siswa sehingga mampu meningkatkan daya serap siswa terhadap materi puisi.

Penelitian menulis puisi pernah dilakukanoleh Julaina Sanusi mahasiswa pascasarjana FKIP UNTAN angkatan ke1. Penelitian dilakukan tahun 2010 dengan judul "Peningkatan Kemampuan Menulis dengan Teknik

Pengelompokkan Pikiran (Mind Clustering) pada Siswa Kelas VII B Semester 2 SMPN 11 Pontianak Tahun Pelajaran 2009/2010". Julaina menggunakan Teknik

Mind Clusteringdalam memecahkan masalah penelitiannya, karenasangat membantu danmempermudah siswa dalam menulis puisi serta dapat mengembangkan kompetensinya secara lebih spesifik dengan latihan yang intensif.

Tujuan penelitian ini adalah (1) mendeskripsikan perencanaan pembelajaran menulis kreatif puisi dengan menggunakan model pembelajaran KKR pada siswa kelas VII A MTs Negeri 2 Pontianak; (2) mendeskripsikan pelaksanaan pembelajaran menulis kreatif puisi dengan menggunakan model pembelajaran KKR pada siswa kelas VII A MTs Negeri 2 Pontianak; (3) mendeskripsikan hasil pembelajaran menulis kreatif puisi dengan menggunakan model pembelajaran KKR pada siswa kelas VII A MTs Negeri 2 Pontianak.

Menurut Tarigan (1993:21), menulis merupakan kegiatan menurunkan atau melukiskan lambang-lambang bahasa yang dipahami seseorang, sehingga orang lain dapat membaca lambang-lambang grafik tersebut.Seseorang dapat dikatakan terampil menulis, apabila ia memiliki kecakapan dalam membuahkan karya 
imajinatif yang singkat dan padat melalui tulisan/ kalimat-kalimat yang produktif.

Menurut Darmadi (1996:31), "kemampuan menulis tidak terlepas dari proses kreatif, sebab proses inilah yang akan melahirkan sebuah karya atau tulisan yang berharga bagi penulis dan pembacanya. Tinggi rendahnya kualitas sebuah tulisan sangat dipengaruhi oleh proses kreativitas penulisnya. Semakin tinggi kualitas proses kreativitas seorang penulis biasanya akan melahirkan karya yang juga semakin baik".Menurut Mulyono (dalam Alisyahbana, 1983:51) kreativitas merupakan pemikiran seseorang, kecerdasan, kepandaian seseorang, kemampuan untuk menciptakan atau menemukan hal-hal baru, hubungan-hubungan baru, proses pada manusia untuk sampai pada caracara baru dalam memecahkan permasalahan dalam hidup, kreasi-kreasi baru untuk menghasilkan objek-objek atau bentuk-bentuk baru dan kelincahan pemikiran orang.

Menurut Bakar (2008:17), puisi adalah curahan jiwa atau luapan hati seorang penyair yang disampaikan secara spontan seraya mengandung perasaan perasaan penuh daya bayang, irama, dan keindahan.Kosasih (2008:31) mengatakan bahwa puisi merupakan salah satu bentuk hasil karya sastra yang tersaji secara monolog, menggunakan kata-kata yang indah, kaya akan makna.Adapun kekayaan makna yang terkandung dalam puisi disebabkan oleh pemadatan segala unsur bahasa.Katakata dalam puisi yang dihasilkan biasanya merupakan ekspresi dan sesuai dengan suasana hati.

Dalam sebuah puisi selalu mengandung beberapa unsur, baik unsur fisik maupun unsur batin. Unsur fisik puisi meliputi: diksi,pengimajian, kata konkret, bahasa figuratif, verifikasi, tipografi, dan sarana retorika. Sedangkan unsur batin puisi meliputi tema, perasaan, nada, suasana, dan amanat.Peranan diksi dalam puisi memiliki arti penting, karena katakataadalah segala-galanya dalam puisi. Karena puisi adalah bentuk karya tulis yang tidak memakai banyak kata-kata, cenderung tidak deskriptif dan naratif, maka pemilihan kata-kata yang tepat untuk menggambarkan maksud dan nuansa tulisan haruslah dicermati dengan seksama termasuk di dalamnya menghindari pengulangan kata yang sama terlampau sering, pemilihan sinonim yang mewakili, sampai ke penggunaan tanda baca dan susunan bahasa.

Untuk memberikan gambaran yang jelas dalam sebuah puisi diperlukan penginderaan untuk menarik perhatian pembaca dan untuk menghidupkan indera pembaca, sehingga pembaca seakan-akan melihat (visual), mendengar bunyi suara (auditif),merasakan rangsangan kepada perasaan atau sentuhan (taktil), penciuman, dan pencecap. Selain itu dalam puisi diperlukan majas atau bahasa figuratif yang berfungsi untuk memudahkan pembaca dalam menikmati sesuatu yang disampaikan oleh penyair.

Model pembelajaran yang dapat digunakan dalam menulis kreatif puisi diantaranya adalah model pembelajaran kreatif, kontekstual, dan religius (KKR).Menurut Amin (2007:332), pembelajaranKKR adalah "sebuah konsep pembelajaran yang berusaha menciptakan suasana pembelajaran yang dinamis dan merangsang munculnya ideide kreatif, adanya interaksi pembelajaran yang mengomunikasikan dan mengembangkan kecakapan hidup, serta berusaha menanamkan nilai-nilai spiritual keagamaan/religius". Langkah-langkah pembelajaran KKR disebut juga dengan desain ICARE yaitu (1) introduce (memperkenalkan), guru menjelaskan kepada siswa tentang tujuan pembelajaran dengan menjelaskan kompetensi dasar dan indikator-indikator yang akan dicapai dalam kegiatan belajar. (2) connect (menghubungkan), guru mendorong siswa untuk menghubungkan materi yang dipelajari dengan pengetahuan, keterampilan, dan pengalaman yang sudah dimiliki siswa. (3) apply (menerapkan), 
guru mampu membimbing dan mendorong siswa untuk mempraktikkan apa yang telah dipelajari.(4) reflect (merefleksikan), artinya mengartikulasikan pengetahuan yang sudah dipelajari dengan cara lisan atau tulisan.(5) extend (menambah atau memperluas), guru mendorong siswa agar bisa merencanakan apa yang akan dilakukan untuk belajar lebih banyak, mendapatkan informasi lebih banyak, dan memiliki kecakapan lebih banyak pula dari materi yang sudah dipelajari.

Di samping itu, model pembelajaran KKR memiliki kelebihan, di antaranya:

(1) menciptakan pembelajaran yang mampu melahirkan inisiatif siswa untuk tampil sebagai siswa yang kreatif. (2) mampu mengembangkan cara berpikir siswa untuk mengaitkan materi pembelajaran dengan konteks dunia nyata yang dihadapi siswa sehari-hari, baik lingkungan keluarga, masyarakat, alam sekitar, maupun dunia kerja yang merangsang pembentukan struktur fisik berpikir dalam rangka merespon lingkungannya sesuai dengan kerja alam, yaitu saling kebergantungan, diferensiasi, dan pengaturan diri. (3) nilai-nilai religius dapat memberi makna pada kehidupan siswa.

\section{METODE}

Metode yang digunakan dalam penelitian ini adalah metode deskriptif. Metode deskriptif merupakan suatu metode yang mengungkapkan, menggambarkan, mendeskripsikan, menguraikan, dan memaparkan objek penelitian. Metode ini digunakan untuk memecahkan masalah yang diteliti dengan memanfaatkan interaksi partisipasi antara peneliti, guru, siswa, dan kepala sekolah yang saling mendukung antara satu dengan lainnya. Metode ini digunakan untuk menggambarkan dan menginterpretasikan kemampuan siswa kelas VII A MTs Negeri 2 Pontianak tahun pembelajaran 2012/2013.

Bentuk penelitian yang digunakan adalah penelitian kualitatifdisebut juga penelitian naturalistik, karena penelitiannya dilakukan pada kondisi yang alamiah (natural setting). Dalam penelitian ini, peneliti akan memaparkan data berdasarkan fakta-fakta yang ditemukan di lapangan atau menggambarkan apa yang (sedang) terjadi. Kemudian data tersebut akan dianalisis untuk memperoleh hasil dari penelitian yang dilakukan. Data yang disajikan dapat berupa kata-kata atau kalimat dan dapat juga berupa angka.

Penelitian ini merupakan Penelitian Tindakan Kelas (PTK). PTK dilaksanakan secara kolaboratif, artinya peneliti berkolaborasi dengan guru bidang studi bahasa dan sastra Indonesia. Kolaborasi yang peneliti lakukan kolaborator mulai dari tahap penyusunan rencana tindakan, pelaksanaan tindakan, pengamatan, kemudian dilanjutkan dengan refleksi berupa diskusi-diskusi yang bersifat analitik dan evaluatif terhadap kegiatan siklus pertama. Selanjutnya mempersiapkan rencana modifikasi, koreksi, dan penyempurnaan pada siklus kedua dan seterusnya.PTK ini dilaksanakan dalam empat tahap, yaitu perencanaan (planning), pelaksanaan tindakan (acting), pengamatan (observing), dan refleksi (reflecting).

\section{HASIL PEMBELAJARAN DAN PEMBAHASAN \\ Hasil}

Aspek yang dinilai dalam pedoman penilaian menulis kreatif puisi meliputi:mendata kata yang tepat berdasarkan objek yang diamati, unsur diksi, gaya bahasa, dan citraan/imaji. Uraian mengenai skor yang diperoleh siswa dalam penilaian menulis kreatif puisi pada setiap siklus sebagai berikut:

\section{Hasil Penilaian Siswa Menulis Kreatif Puisi Siklus I}

Uraianmengenai skor yang diperoleh siswa secara individu dalam menulis kreatif puisi pada siklus I sebagai berikut: a. Mendata kata yang tepat berdasarkan objek yang diamati.Skor maksimal mendata kata yang tepat adalah 10, karena kata-kata yang didata menurut instruksi guru berjumlah 10 
kata berdasarkan panca indera yang berkenaan dengan keindahan alam di sekitar sekolah. Siswa yang mendapat skor 10 berjumlah 16 orang, dengan persentase $55,17 \%$. Siswa yang mendapat skor 9 berjumlah 5 orang dengan persentase $17,24 \%$. Siswa yang mendapat skor 8 berjumlah 2 orang dengan persentase $6,89 \%$. Siswa yang mendapat skor 7 berjumlah 3 orang dengan persentase $10,34 \%$. Siswa yang mendapat skor 6 berjumlah 3 orang dengan persentase $13,79 \%$. b. Menulis/menyusun kata-kata yang didata menjadi sebuah puisi dengan memperhatikan diksi yang tepat.Siswa yang mendapat skor 5 berjumlah 3 orang dengan persentase $13,79 \%$. Siswa yang mendapat skor 4 berjumlah 16 orang dengan persentase $55,17 \%$. Siswa yang mendapat skor 3 berjumlah 10 orang dengan persentase $34,48 \%$. a. Menulis/menyusun

kata-kata yang didata menjadi sebuah puisi dengan menggunakan gaya bahasa. Siswa yang mendapat skor 5 berjumlah 1 orang dengan persentase $3,44 \%$. Siswa yang mendapat skor 4 berjumlah 2 orang dengan persentase $6,89 \%$. Siswa yang mendapat skor 3 berjumlah 15 orang dengan persentase $51,72 \%$. Siswa yang mendapat skor 2 berjumlah 4 orang dengan persentase $17,24 \%$. Siswa yang mendapat skor 1 berjumlah 7 orang dengan persentase $24,13 \%$. a. Menulis/menyusun kata-kata

yang didata menjadi sebuah puisi dengan menggunakan citraan/pengimajian.Siswa yang mendapat skor 3 berjumlah 10 orang dengan persentase $34,48 \%$. Siswa yang mendapat skor 2 berjumlah 14 orang dengan persentase $48,27 \%$. Siswa yang mendapat skor 1 berjumlah 5 orang dengan persentase $17,24 \%$

\section{Tabel 1}

Nilai Rata-rata Siswa Menulis Kreatif Puisi pada Siklus I

\begin{tabular}{|c|c|c|c|c|c|c|}
\hline$\overline{\mathrm{No}}$ & Keterangan & $\begin{array}{l}\text { Jumlah } \\
\text { Siswa }\end{array}$ & $0-71$ & $\begin{array}{l}\text { Nialai } \\
72-100\end{array}$ & $\begin{array}{l}\text { Rata-rata } \\
\text { Kelas }\end{array}$ & $\begin{array}{l}\text { Ketuntasan } \\
\text { Belajar }\end{array}$ \\
\hline 1 & Siklus I & 29 & & $\begin{array}{l}17 \text { siswa } \\
(58,62 \%)\end{array}$ & 69,65 & 41,38 \\
\hline
\end{tabular}

\section{Hasil Penilaian Siswa dalam Menulis Kreatif Puisi Siklus II}

Uraikan mengenai skor yang diperoleh siswa secara individu dalammenulis kreatif puisi pada siklus II sebagai berikut: a. Mendata kata yang tepat berdasarkan objek yang diamati.Skor maksimal mendata kata yang tepat adalah 10, karena kata-kata yang didata menurut instruksi guru berjumlah 10 kata berdasarkan panca indera yang berkenaan dengan keindahan alam di sekitar sekolah. Siswa yang mendapat skor 10 berjumlah 22 dengan persentase $75,86 \%$.

Siswa yang mendapat skor 9 berjumlah 4 orang dengan persentase $17,24 \%$. Siswa yang mendapat skor 8 berjumlah 1 orang dengan persentase $3,44 \%$. Siswa yang mendapat skor 7 berjumlah 1 orang dengan persentase $3,44 \%$. Siswa yang mendapat skor 6 berjumlah 1 orang dengan persentase 3,44\%. b. Menulis/menyusun kata-kata yang didata menjadi sebuah puisi dengan memperhatikan diksi yang tepat. Siswa yang mendapat skor 5 berjumlah 3 orang dengan persentase $10,34 \%$. Siswa yang mendapat skor 4 berjumlah 19 orang dengan persentase $65,52 \%$. Siswa yang mendapat skor 3 berjumlah 7 orang dengan persentase $24,13 \%$. c. Menulis/menyusun kata-kata yang didata menjadi sebuah puisi dengan menggunakan gaya bahasa. Siswa yang mendapat skor 4 berjumlah 5 orang dengan persentase $17,24 \%$. Siswa yang mendapat skor 3 berjumlah 9 orang dengan persentase $31,03 \%$. Siswa yang mendapat skor 2 berjumlah 7 orang dengan persentase

$24,13 \%$. Siswa yang mendapat skor 1 berjumlah 8 orang dengan persentase 
$27,58 \%$. a. Menulis/menyusun kata-kata yang didata menjadi sebuah puisi dengan menggunakan citraan/pengimajian.Siswa yang mendapat skor 4 berjumlah 1 orang dengan persentase $3,45 \%$. Siswa yang mendapat skor 3 berjumlah 18 orang dengan

\section{Tabel 2}

Nilai Rata-rata Siswa Menulis Kreatif Puisi pada Siklus II

\begin{tabular}{lllcccc}
\hline No & Keterangan & Jumlah & \multicolumn{2}{c}{ Nilai } & Rata-rata & Ketuntasan \\
& & Siswa & $0-71$ & $72-100$ & Kelas & Belajar \\
\hline 1 & Siklus II & 29 & 18 siswa & 21 siswa & 73,79 & $72,41 \%$ \\
& & Orang & $(62,07 \%)$ & $(72,41 \%)$ & & \\
\hline
\end{tabular}

\section{Hasil Penilaian Siswa dalam Menulis Kreatif Puisi Siklus III}

Penilaian hasil pada siklus III ini adalah penilaian portofolio menulis puisi.Dalam penilaian menulis puisi dengan model pembelajaran KKR dilakukan melalui 4 aspek.Uraian mengenai skor yang diperoleh siswa secara individu dalam menulis kreatif puisi pada siklus III sebagai berikut: (a). Mendata kata yang tepat berdasarkan objek yang diamati.Skor maksimal mendata kata yang tepat adalah 10, karena kata-kata yang didata menurut instruksi guru berjumlah 10 yang berkenaan dengan keindahan alam di sekitar sekolah. Siswa yang mendapat skor 10 berjumlah 26 dengan persentase $89,66 \%$.

Siswa yang mendapat skor 9 berjumlah 3 orang dengan persentase $10,34 \%$. b. Menulis/menyusun kata-kata yang didata menjadi sebuah puisi dengan memperhatikan diksi yang tepat.Siswa yang mendapat skor 5 berjumlah 8 orang dengan persentase $27,59 \%$. Siswa yang mendapat skor 4 berjumlah 19 orang dengan persentase $65,52 \%$. Siswa yang mendapat skor 3 berjumlah 1 orang dengan persentase $3,45 \%$. Siswa yang mendapat skor 2 berjumlah 1 orang dengan persentase $3,44 \%$. c. Menulis/menyusun kata-kata yang didata menjadi sebuah puisi dengan menggunakan gaya bahasa. persentase $62,06 \%$. Siswa yang mendapat skor 2 berjumlah 9 orang dengan persentase $31,03 \%$. Siswa yang mendapat skor 1 berjumlah 1 orang dengan persentase $3,45 \%$.
Siswa yang mendapat skor 5 berjumlah 3 orang dengan persentase $10,34 \%$. Siswa yang mendapat skor 4 berjumlah 4 orang dengan persentase $13,79 \%$. Siswa yang mendapat skor 3 berjumlah 15 orang dengan persentase $51,72 \%$. Siswa yang mendapat skor 2 berjumlah 4 orang dengan persentase $13,79 \%$. Siswa yang mendapat skor 1 berjumlah 3 orang dengan persentase 10,34\%. a. Menulis/menyusun kata-kata yang didata menjadi sebuah puisi dengan menggunakan citraan/pengimajian.Siswa yang mendapat skor 3 berjumlah 16 orang dengan persentase $55,17 \%$. Siswa yang mendapat skor 2 berjumlah 11 orang dengan persentase $37,93 \%$. Siswa yang mendapat skor 1 berjumlah 2 orang dengan persentase $6,89 \%$.

Tabel 3 menyatakan persentase ketuntasan belajar siswa yang mengikuti pembelajaran menulis kreatif puisi dengan menggunakan model pembelajaran KKR pada siklus III sebesar $89,66 \%$. Hal ini menunjukkan bahwa pada siklus III siswa sudah mengalami ketuntasan dalam pembelajaran menulis kreatif puisi yang telah ditentukan oleh MTs Negeri 2 Pontianak yaitu 72, dan sudah memenuhi syarat dari indikator kinerja sekurangkurangnya $80 \%$ nilainya 72 . 
Tabel 3

Nilai Rata-rata Siswa Menulis Kreatif Puisi pada Siklus III

\begin{tabular}{lllcccc}
\hline No & Keterangan & Jumlah & Nilai & Rata-rata & Ketuntasan \\
& & Siswa & $0-71$ & $72-100$ & Kelas & Belajar \\
\hline 1 & Siklus III & 29 & 3 siswa 26 siswa & 78,20 & $89,66 \%$ \\
& & Orang & $(10,34 \%)$ & $(89,66 \%)$ \\
\hline
\end{tabular}

Adapun nilai rata-rata siswa dalam menulis kreatif puisi dengan menggunakan model pembelajaran KKR pada setiap siklus dapat dilihat pada tabel berikut:

Tabel 4

Nilai Rata-rata Siswa Menulis Kreatif Puisi dengan Menggunakan Model Pembelajaran KKR pada Setiap Siklus

\begin{tabular}{llll}
\hline No & Keterangan & Nilai Rata-rata & Persentase \\
\cline { 2 - 4 } 1 & Siklus I & 69,65 & $41,38 \%$ \\
2 & Siklus II & 73,79 & $72,41 \%$ \\
3 & Siklus III & 78,20 & $89,66 \%$ \\
\hline
\end{tabular}

Berdasarkan tabel di atasdapat diketahui bahwa dengan menggunakan model pembelajaran KKR dapat meningkatkan nilai rata-rata siswa dalam menulis kreatif puisi. Sebelum diadakan tindakan, rata-rata nilai siswa 68,00 . Setelah diadakan tindakan pada siklus I, nilai rata-rata siswa 69,65 berarti mengalami peningkatan 1,65. Dilanjutkan tindakan siklus II mengalami peningkatan sebesar 4,14 menjadi 73,79. Pada tindakan siklus III mengalami peningkatan sebesar 4,41 menjadi 78,20. Jadi, setelah diadakan tindakan sebanyak tiga siklus, maka secara keseluruhan mengalami peningkatan sebesar 10,2. Untuk lebih jelasnya dapat dilihat pada gambar berikut:

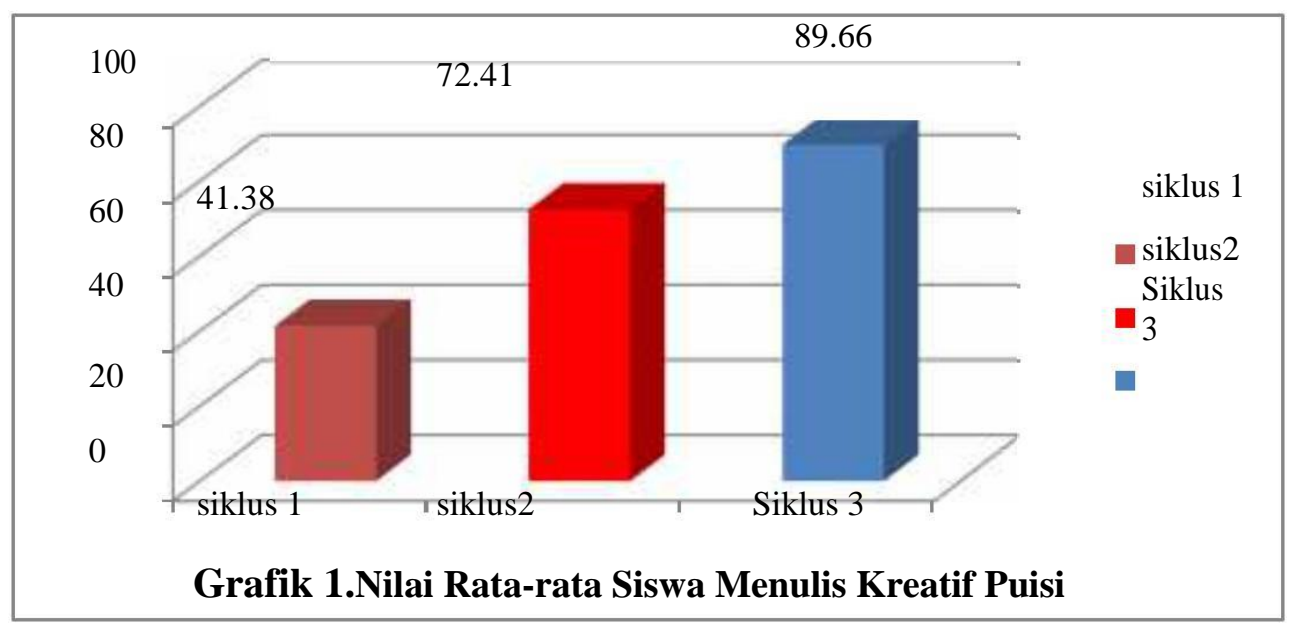




\section{KESIMPULAN DAN SARAN Simpulan}

Berdasarkan hasil penelitian tindakan kelas yang dilakukan, dapat disimpulkan beberapa hal berikut ini. (1) Perencanaan pembelajaran menulis kreatif puisi dengan menggunakan model pembelajaran KKR pada siswa kelas VII A MTs Negeri 2 Pontianak tahun pembelajaran 2012/2013 siklus I,II,dan IIIdirencanakan $2 \mathrm{x}$ pertemuan pada tiap siklus.(2) Pelaksanaan pembelajaran menulis kreatif puisi dengan menggunakan model pembelajaran KKR pada siswa kelas VII A MTs Negeri 2 Pontianak tahun pembelajaran 2012/2013 mengalami peningkatan setelah diberi tindakan sebanyak 3 siklus.(3) Hasil pembelajaran menulis kreatif puisi yang diperoleh siswa tiap siklus mengalami peningkatan. Siklus I rata-rata hasil pembelajaran menulis kreatif puisi adalah 69,65 ketuntasan belajar secara klasikal sebesar 41,38\%terdiri dari 12 orang. Siswa yang tidak tuntas sebesar 58,62\% terdiri dari 17 orang. Siklus II rata-rata 73,79 ketuntasan belajar secara klasikal sebesar 72,41\%terdiri dari 21 orang. Siswa yang tidak tuntas sebesar $27,58 \%$ terdiri dari 8orang. Sedangkan siklus III

\section{DAFTAR RUJUKAN}

Alisyahbana, S. Takdir. 1983. Kreativitas. Jakarta: PT Dian Rakyat.

Amin, M. Thaib, dkk. 2007. Model Pembelajaran pada Madrasah Tsanawiyah.

Jakarta: Balai Litbang Agama.

Amri, Sofan dan Ahmadi, IIF Khoiru. 2010. Proses Pembelajaran Kreatif dan Inovatif dalam Kelas. Jakarta: Prestasi Pustaka. rata-rata 78,20 ketuntasan belajar secara klasikal sebesar 89,66\%, terdiri dari 26 siswa. Siswa yang tidak tuntas sebesar $10,34 \%$ terdiri dari 3 orang.

\section{Saran}

Saran yang dapat disampaikan peneliti berdasarkan hasil penelitian sebagai berikut: (1) Model pembelajaran KKR diharapkan dapat menjadi salah satu solusi perbaikan pendidikan ke depan sehingga melahirkan output ideal yang menjadi harapan semua pihak, khususnya guru. (2) Model pembelajaran ini juga cocok diterapkan di sekolah-sekolah. (3) Guru mata pelajaran Bahasa Indonesia diharapkan dapat menggunakan model pembelajaran KKR atau metode lain yang bervariasi untuk meningkatkan kemampuan siswa menulis kreatif puisi dengan langkah-langkah pembelajaran yang sesuai. (4) Sebaiknya guru mata pelajaran Bahasa Indonesia memiliki kemampuan mengajar dengan baik, dapat mengelola kelas, serta dapat menggunakan model pembelajaran yang sesuai dalam skenario pembelajaran dengan tepat.

Bakar, Hamidi. 2008. Mengenal Sastra. Jakarta: CV Indradjaya.

Darmadi, Kaswan. 1996. Meningkatkan Kemampuan Menulis. Yogyakarta: ANDI

Kosasih. 2008. Apresiasi Sastra Indonesia. Jakarta: Nobel Edumedia

Tarigan, Henry Guntur. 1993. Menulis Sebagai Suatu Keterampilan Berbahasa. Bandung: Angkasa 